Dr. sc. Rustem Qehaja, associated professor

Armend Ahmeti, student of Master's studies

University of Pristina "Hasan Pristina", Faculty of Law, Kosovo

\title{
THE LEGAL REGULATION OF ARBITRATION IN KOSOVO, WITH SPECIAL EMPHASIS ON THE INSURANCE POLICY
}

\author{
UDK: 347,918 (497. 115) \\ Primljeno: 15. 04. 2018. \\ Pregledni znanstveni rad
}

\begin{abstract}
The subject about which this study is conducted relates to arbitration, as a method or alternative way of resolving disputes from insurance policy. The topic discussed in this paper is of particular importance because industry of insurance activity represents a rather delicate activity, which considerably arises interest in citizens, because through insurance they secure the most fundamental goods such as life, wealth and so on. During the course of this study, I have focused on the provisions of various laws covering the insurance sector such as Law no. 04/L-077 on Obligations, Law no. 05/L-045 on Insurance, etc., as well as in the legislation, which covers the field of arbitration in Law no. 02/L-75 on Arbitration of the Republic of Kosovo. The settlement of disputes by the insurance policy between the parties through arbitration gives this subject a specific character, because the use of arbitration in this field is not studied and analyzed as much as is necessary. The purpose of this paper is to provide the reader with general knowledge on arbitration as an alternative way of resolving disputes between the parties to the insurance.
\end{abstract}

Key words: Arbitration, Insurance, Insurance Policy, Law on Insurance, Law on Arbitration.

\section{INTRODUCTION}

This brief study has to do with arbitration, as an alternative way for solving disputes from the insurance policy. Topics are sorted by starting from the coverage of the insurance, the phenomenon, the role and importance of insurance in general, the legal definition of the notion of insurance, insurance policy and activity exercised by insurance companies, etc., then with the meaning of the dispute, proceeding further with the reflection of the understanding and functioning of the arbitration in general, the arbitration agreement, the arbitration clause, the coniditions for being a succesful arbitrator, the advantages and disadvantages of arbitration, etc., as an alternative legal remedy of dispute resolution in general, and finally, 
the use of arbitration for solving disputes from the insurance policy in particular.

\section{THE PHENOMENON, THE ROLE AND THE IMPORTANCE OF INSURANCE}

The term "insurance" in the etymological sense, represents security, trust, protection, guarantee, protection from any circumstances that will arise. The phrase "insurance" in Oxford dictionary has this meaning: "An arrangement by which a company or the state undertakes to provide a guarantee of compensation for specified loss, damage, illness, or death in return for payment of a specified premium"'. In the literature, it is noted that the first insurance policy was found in 1182 in Lombardi. The insurance sector is regulated in legal terms with the provisions of the Law on Insurance (hereinafter LI) ${ }^{2}$ and the Law on Obligations (hereinafter LO) ${ }^{3}$ of the Republic of Kosovo. In Section XXIV "Insurance Contract" of LO, respectively in Article 918, is defined the concept of the insurance contract, which states that "with the insurance contract is owed the insurance contractor who on the principles of reciprocity and solidarity pays a certain amount to the company (the insurer), and the company is obliged to pay the insured or any third person, the remuneration, respectively the contracted amount or do something else, if the occurrence of the insured event occurs". Whereas, Article 3, paragraph 1, sub-paragraph. 1.27 of the LI with the term "Insurance" means the transfer of a potential risk of a property and / or non-life loss from the insured to the insurer under an insurance contract. LI, according to the latin legal maxims "lex posterior derogat legi prior" and "lex specialis derogat legi generali" has greater legal power than the provisions of LO, because LS is firstly a special law. In this we conclude also according to the provision of Article 2 of this law, and that the LI has entered into force, after the entry into force of the LO.

In view of their participation in the insurance, subjects of insurance relationship can be divided into:

a) compulsory insurance participants, and

b) non-compulsory (optional) participants.

Without compulsory insurance participants there can not be insurance, while optional participants appear periodically on insurance. The legal elements of insurance are:

1 Oxford Dictionary [online], available at: https://en.oxforddictionaries.com/definition/insurance , accessible on 16.12.2017.

2 Law no. 05 / L -045 on Insurance, 30 November 2015, Promulgated by Decree no. DL-035-2015, dated 16.12.2015 by the President of the Republic of Kosovo, Atifete Jahjaga.

3 Law no. 04 / L-077 on Obligations, Promulgated by Decree No.DL-024-2012, dated 30.05.2012 by the President of the Republic of Kosovo, Atifete Jahjaga. 

insured;

b. risk;

c. secured case;

d. insurance element;

e. insurance reimbursement;

f. the amount of insurance;

g. duration of the insurance.

The term "insurer" under Article 3, par. 1, sub.p 1.32 of LI, means a legal person licensed to carry out insurance activities according to the provisions of this law, while the same provision but sub-section. 1.33, stipulates that the term "insured" means a person whose potential and / or non-property loss is subject to an insurance contract. In life insurance contracts, the insured is a natural person whose life is insured. The primary activity of insurers is the sale of policies, respectively the provision of insurance services for various insurance products, which according to a "thick line" can be classified as compulsory insurance, and voluntary insurance, or in:

1. Insurance of persons;

2. Insurance of guarantees;

3. Property Insurance;

4. Insurance of responsibilities; and

5. Vehicle insurance ${ }^{4}$.

Selling the insurance policy ${ }^{5}$ for the particular insurance product is a special and important moment. The insurance contract is concluded when the contractors sign the insurance policy or the cover list ${ }^{6}$. What should be written in the insurance policy is regulated by Article 923, par. 1 of $\mathrm{LO}^{7}$. However, for the life insurance policy, as a separate insurance policy, apart from the constituent parts of any policy, the life insurance policy should include: the name and surname of the person in whose life the insurance is extended, his or her date of birth, the event or deadline from which the right to claim the payment of the insured amount depends ${ }^{8}$. The moment of the

4 Qehaja, Rr. (2012). Arbitration - as a way of resolving disputes from insurance policy, Journal of Legal and Social Issues ' $L A W$ ", University of Pristina, Faculty of Law, page 71.

5 According to Article 2, par. 1, sub. 1.23 of the Law no. 04 / L-018 for compulsory motor liability insurance (hereinafter: LCMLI), 23 June 2011, the term "insurance policy" has the meaning of the motor liability insurance contract, respectively the standardized insurance certificate signed by the insurer and the insured, which confirms the contracting of the liability insurance.

${ }^{6}$ Article 922, par. 1 of LO.

7 Article 923, par.1 of LO stipulates that: "In the police must be written the contracting parties, the insured item, respectively the insured person, the risk covered by the insurance, the duration of the insurance and the period of the deposit, the amount of insurance or that insurance is unlimited, premiums or contributions, the date of the policy award and the signatures of the contracting parties ".

${ }^{8}$ Article 964, par. 1 of LO. 
occurrence of the insured event as a future event, uncertain and independent of the exclusive will of the insurance policy contractors, constitutes a crucial moment both for the insurer and the insured. Among others, for the insurance contractor, the obligation to notify the filing of an insurance case in accordance with Article 938, par. 1 of LO is set ${ }^{9}$. The moment of the occurrence of the insured event also imposes obligations on the insurer, as noted above. For example, when the insured event occurs, the insurer has a duty to pay the reward or the amount determined by contract within the contracted term, which can not be longer than fourteen (14) days, counting from the date when the insurer have received notice that the insured event has occurred ${ }^{10}$. Pursuant to Article 26, par. 1 of LCMLI "The Insurer shall be liable for damages in person, at most within 60 days, and for damage to property, at the latest within 15 days from the filing date of the claim for damages by the injured party, to address the claim and to notify in writing the injured party with the compensation offer with the relevant explanation or the legal decision and reasons for refusing the claim for damages, where the content and the amount of the damage are contested". "The injured party has the right to file a lawsuit with the competent court, if the insurer misses the abovementioned legal deadlines" 11 .

The Kosovo Security Bureau, which is a professional organization with a legal entity quality, is supervised and shall submit to the Central Bank of the Republic of Kosovo (hereinafter: CBK) annually, an annual report on the exercise of its public authorizations. CBK oversees the operation of damages treatment procedures by insurance companies to guarantee the defense and, respectively, the indemnification of the injured party. "CBK undertakes administrative measures against the insurance company licensed by CBK to conduct compulsory motor liability insurance activities as follows:

1. Announce in the means of information, at the expense of the insurer, data on the incorrect behavior of the insurer responsible for the treatment of damages;

2. withdraws the approval of the members of the insurance insurer's governing bodies, temporarily or definitively withdraws the license to perform the activity in the field of compulsory insurance" $"$.

\section{THE MEANING OF DISPUTE AS A LEGAL RELATIONSHIP}

In a "dispute", one must understand the situation in which a person claims to have a subjective civil right to another person, but the other person denies her existence or by any other cause denies her/his obligation to behave in a certain

9 Article 938, par. 1 of LO, which stipulates that: "The insurance contractor is obliged, except in the case of life insurance, to notify the insurer of the filing of the insurance case no later than three (3) days from when he is brought aware of this".

10 Article 940, par.1 of LO.

11 Article 26, paragraph 5 of LCMLI.

12 Article 27, paragraph 3 of LCMLI. 
manner ${ }^{13}$. "As a legal relationship the dispute was born on the basis of many legal processes and procedural legal status"14. "Dispute" represents a dispute between the litigants, ie the plaintiff and the defendant regarding any civil-legal matter. I recall that, there are three basic subjects in the civil-legal dispute: the plaintiff, the defendant and the court. The dispute arises at the moment of submission of the lawsuit to the opposing party (the respondent), so at that moment litispendence is created. The question arises, what constitutes a subjective civil right? "A subjective civil right represents legal power, which consists of one or more authorizations, which serve to fulfill personal interests" ${ }^{\prime \prime}$. What is a subjective right for one subject of the law is an obligation of the other subject of the law. For example, in a sales contract, the seller is obliged to deliver the thing to the buyer and to transfer the right of disposal or property, and the buyer is obliged to pay the specified amount of money on behalf of the buyer price. The disputed situation among the subjects of the law is resolved by the competent state body. "Everyone has the right to address to the court to seek the protection and enforcement of his lawful rights"16. The Law on Contested Procedure ${ }^{17}$ (hereafter: LCP) in its Article 2, par. 3 has established the principle that the court can not refuse to examine and decide on the claims that fall within its competence. A distinction must be made between the dispute and the contested process, because these two notions are completely different from one another. The "dispute" shows the situation in which a subject of the law claims a right respectively, a legal or a natural person claims a right, while the other subject of the law denies the existence of this right, while the contested process is the judicial path to be followed to resolve this despute between the subjects of the law.

\section{IN GENERAL ABOUT ARBITRATION AS A WAY OF RESOLVING DISPUTES}

Basically, the courts come to us first in mind when confronted with a dispute, consequently, for resolving that dispute. However, apart from the courts there are other dispute resolution mechanisms, which exist in parallel with the courts. Alternative methods such as dispute resolution mechanisms are: negotiation, mediation, arbitration, and judicial settlement, which in today's legal terminology are called "Alternative Dispute Resolution Methods"18. "Kosovo has no long history

13 Brestovci, F. (2006). Civil procedural law (4th edition). Pristina, Kosovo: University of Pristina, Faculty of Law, page 12.

14 Musa, M. (2015). Civil procedural law (1st edition). Gjilan, Kosovo: Published by House Print "Point $5 A$ ", page 26.

15 Brestovci, F., citated book, page 11

16 Law no. 03 / L-199 on Courts, July 22, 2010. This law comes into force on 1 January 2011 for Articles 29, 35, 36, 38 and 40, while for other articles begins to apply from 1 January 2013.

17 Law no. 03/L-006 on Contested Procedure of the Republic of Kosovo, promulgated by Decree no. DL-045-2008, dated 29.07.2008 by the President of the Republic of Kosovo, Dr. Fatmir Sejdiu.

18 Musa, M., citated book, page 92. 
of using arbitrage as a mechanism for settling disputes. There are very rare cases when businesses anticipate arbitration in case of eventual disagreements, although recent times the number of these cases is increasing, especially when the parties to the contract come from two different countries, so when we have agreements with an international element"19.

"The term "arbitration" according to the Cambridge vocabulary has the meaning of the process of resolving a dispute between people, helping them to agree on an acceptable solution" ${ }^{20}$. Arbitration is an elected court, which the parties form by agreement and agree (consent) that the arbitration verdict for them be final (binding) and enforceable, respectively to fulfill voluntarily or through execution by the court. Arbitration as an alternative legal mechanism is used, in particular, by economic (commercial) entities to resolve disputes between them. Arbitration procedure means actions taken from the moment of filing a request for arbitration by the plaintiff until the decision of the arbitral tribunal. As the main actions in an arbitration procedure are set out: the request for arbitration, usually filed by the plaintiff, the response to the lawsuit filed by the defendant, the appointment of an arbitrator or arbitrators, the constitution of the arbitral tribunal, the commencement of oral hearings, the presentation of evidence (witnesses, experts, etc.), examination by the arbitral tribunal, issuing the verdict and finally the execution of arbitral verdict. "In accordance with these rules, the arbitral tribunal may conduct arbitration in such a way as it deems appropriate, provided that the parties are treated equitably and that at any appropriate stage of the proceedings each party has been given a reasonable opportunity to present her case. The arbitral tribunal, in exercising its discretion, will guide the procedure in order to avoid unnecessary delays and expenses and to ensure a fair and efficient dispute resolution process" 21 . "As soon as possible after its formation and after the parties have been invited to express their views, the arbitral tribunal shall determine the interim arbitration time, which shall be delivered to the parties and, for information, to the arbitration institution. The arbitral tribunal may, at any time after having invited the parties to express their views, extend or shorten any period of time determined pursuant to such rules or agreed upon by the parties. The arbitral tribunal provides the revised schedule of the arbitration institution"22.

Law on Arbitration (hereafter: LA) ${ }^{23}$ does not contain the provision on which the definition of arbitration is made. However, in Article 2, par. 1. of this law we may find the definition of the term "Arbitration Agreement", which means the agreement

19 "Manual for the Preparation of Jurisprudence Exam - The part of civil procedural law", Third Edition, Kosovo, Pristina, 2008, page 911.

20 Cambridge Dictionary [online], available at: http://dictionary.cambridge.org/dictionary/english/ arbitration, accessible on 16.12.2017.

21 Summary of Arbitration Rules , American Chamber of Commerce, Entry Rules, April 19, 2011, Article 17, par.1.

22 Summary of Arbitration Rules, American Chamber of Commerce, Entry Rules, Article 17, par.2.

23 Law no. 02 / L-75, January 26, 2007, on Arbitration. This law shall enter into force one month after its adoption by the Assembly of Kosovo and upon its promulgation by the Special Representative of the Secretary-General. 
reached between two or more persons that some or all legal disputes that have arisen or may arise between them, will be subject to arbitration. In the Republic of Kosovo, the meaning of arbitration can be found in several sources, including:

1. Rule 28 of the CBK on the Establishment of an Arbitration Forum to Address Complaints on Claims dated 01.04.2002;

2. Law on Arbitration no. 02 / L-75 dated 26.01.2007;

3. Rule 10 of the CBK on Amending the Rule on the Establishment of the Arbitration Forum, which entered into force on 29.07.2008;

4. Arbitration Rules of the "Kosovo Chamber of Commerce";

5. Arbitration Rules of the "American Chamber of Commerce"24.

Pursuant to Article 5, par. 1 of LA "A dispute may be settled through arbitration only if there is an agreement of the parties by which they agree to settle the dispute through arbitration". So, the agreement of the parties is the cornerstone of arbitration, without this agreement there can be no arbitration. "The form of the arbitration agreement is defined by law" 25 . The question arises, what the court should do, when for the same dispute, the same parties, contract arbitration for settling the dispute? This issue is regulated by the par. 1 of Article 20 of LCP, which states that: "Upon dismissal of the defendant the court will be declared incompetent, will cancel the actions performed in the proceedings and will dismiss the claim. If the court finds that the contract on arbitration is not valid, has ceased its validity or can not be realized, the court will not act as stated above". The arbitration clause provides a clause within the contract which is concluded between the parties, on the basis of which the parties agree that any dispute between them, regarding the rights and obligations arising from the main contract, be settled through the arbitration route. "This clause constitutes a special legal entity, which has the independent legal fate of the fate of the main contract" 26 . This concept is also supported by LA, respectively in Article 14, par. 1 thereof stipulates inter alia that: "The arbitration clause, which is part of a contract, is treated as a separate and independent contract agreement".

"It is worth pointing out that there can be no valid arbitration agreement if it comes to the dispute for which the exclusive jurisdiction of our court is foreseen" 27 . Also, the arbitration agreement is void if the parties have agreed that the number of members of the arbitral tribunal should be even and not odd. This is because, LA itself, in Article 9, par. 1 has established the condition that in cases when the arbitral tribunal is composed, and subsequently adjudicates by an arbitral body, the number of arbitrators of this body should be odd. 'In the arbitration procedure, the parties' availability is apparent, which availability is only excluded in exceptional cases, e.g

${ }^{24}$ Qehaja, Rr., citated article, page 78.

25 Article 6, par. 1 of LA.

26 Musa, M., citated book, page 99.

27 See relevant provisions of Articles 41, 42 and 43 of the LCP regarding exclusive territorial jurisdiction. 
the agreement of the parties is void, which excludes the principle of contradictory or hearing of the parties" 28 .

"The parties to arbitration are equal, and as such are treated equally and each party should have the full opportunity to present its case at each stage of the arbitration procedure" 29 . The question arises, who initiates the arbitration procedure, with what legal remedy and when? "Within the deadline agreed upon by the parties or, in the absence of such agreement within the deadline set by the arbitral tribunal, the plaintiff is obliged to file his claim and the evidence on which the claim is based, and the defendant has a duty to present the answer in the lawsuit and the evidence on which it relies" 30 . The arbitration procedure is started by the plaintiff with the lawsuit as a legal remedy, and within the time agreed by the parties themselves, or in the absence of such agreement, within the time limit set by the arbitral tribunal. Procedurally, the arbitration procedure begins on the day the request for contesting the dispute is accepted by the defendant, unless the parties have agreed otherwise. The burden of proof of the facts lies on the "shoulders" of the parties. In this context, the arbitral tribunal shall decide on the admissibility, veracity and weight of the facts respectively the evidence presented by the parties. The arbitral tribunal may issue evidence, if it deems it necessary, and make their assessment in a free and fair manner. The conditions for being a successful arbitrator are set out in $\mathrm{LA}^{31}$, and in legal doctrine ${ }^{32}$. These conditions are: the independence of the arbitrator, his impartiality, not to be in conflict of interest with the parties, to have professional skills, to demonstrate efficiency and to be quick in resolving disputes, etc. The arbitration procedure may end in several ways. This procedure usually ends with the issuance of a final decision or an order of the arbitral tribunal. "This order is issued by the arbitral tribunal, and it has legal consequence of termination of the arbitration procedure" 33 .

The advantages of arbitration in resolving disputes compared to regular courts are:

1. The parties themselves by agreement determine the law that will be applied, both material and procedural;

2. Costs are smaller (not always);

3. The speed of dispute resolution;

4. Neutrality of arbitration or arbitrators;

5. Great flexibility (the ability to adapt arbitrage according to the specific needs and circumstances) of the process;

28 Morina, I., \& Nikçi, S. (2012). Commentary on the Law on contested procedure of Republic of Kosovo. Pristina, Kosovo: Deutsche Gesellschaft für Internationale Zusammenarbeit (GIZ), page 831.

29 Article 16, par. 1 of LA.

30 Article 20, par.1 of LA.

31 Article 9, par.6 of LA.

32 Musa, M., citated book, page 103.

33 More specifically see Article 33, par.2 of LA. 
6. Safeguarding the confidentiality of the procedure;

7. Informality of the procedure;

8. The multiple possibility of the parties' participation in the development of the proceedings before the arbitral tribunal eg the appointment of arbitrators;

9. Arbitration decision is final and mandatory for the parties, etc ${ }^{34}$.

However, arbitration has its own shortcomings, or its negative sides, such as:

1. Imposing unjust solutions to the weaker economic party;

2. The possibility of misuse by the parties, because the parties themselves decide on many issues;

3. There is no control of the highest instance ie there is no appeal even if the decision is unfair etc.

\section{ARBITRATION AS A WAY OF SETTLING DISPUTES FROM THE INSURANCE POLICY}

For arbitration as an alternative way of resolving disputes from the insurance policy between the parties of the insurance relationship there is a special legal act issued by the CBK Steering Board. This legal act is named "Regulation on the procedures of the arbitral tribunal (hereafter: RPAT of $C B K$ )" ${ }^{35}$. This regulation applies for insurers (insurance companies), policyholders, insured and third parties. "According to this regulation, arbitration means the dispute resolution procedure in which a neutral third party (referee) after deciding on evidence and facts issues a decision on the dispute in question" ${ }^{36}$. In the sense of the provision of Article 2, point b) "referee" or "referees" mean the individual or group of individuals (panel) appointed by agreement by the parties or by the Court to resolve the dispute. In this case, individuals appointed by the parties as arbitrators can not be arbitrary, so they resolve the issues without complying with the laws and regulations, because this is illogical and obviously contradicts directly the legal norms. "The arbitral tribunal will function as an office for organizing hearings of arbitration, maintain the list of arbitrators, lead other functions necessary for the arbitration panels, and will notify the parties of the decisions of the arbitration panel" ${ }^{37}$. It is a voluntary affair of the injured party, which has insurance coverage to make the right to compensation through the arbitration route. A disagreement can be resolved from the tribunal of arbitration only if a written agreement exists between the parties of the dispute, by

34 Article 31, par. 1 of the LA, which states that "The arbitral tribunal's decision shall be made in writing and shall be final and binding on the parties. The decision to the parties shall have the same legal effect as a final and binding judgment of the court".

35 "Regulation on the procedures of the arbitral tribunal", approved on 30 March 2017 by The Central Bank Board of the Republic of Kosovo in its meeting held on 30 March 2017. This Regulation shall enter into force fifteen (15) days after its adoption by the CBK Board.

36 Article 2 "Definitions", point a) of RPAT of CBK.

37 Article 6, par.3 of RPAT of CBK. 
which they accept that the disagreement shall be resolved from the tribunal of arbitration. The Arbitration Agreement is valid only if it is signed in writing. "Arbitration Agreement is considered to be affixed in writing even when it is linked to the exchange of letters, telegrams or other means that enable written evidence of the completed agreement" 38 . The right to submit a request to arbitration must be exercised within the statutory deadline from the occurrence of a secured case or incidents that result in a harm. It is worth noting that there is a sub-legal act, respectively, a regulation which sets out the unique criteria for the compensation of intangible damages and other damages arising from intangible damages as a result of traffic accidents subject to compulsory motor liability insurance ${ }^{39}$. Pursuant to Article 2, par. 1 of RPAT of CBK, "any person acting in the capacity of a third party who is harmed by the use of a motor vehicle subject to compulsory motor liability insurance has the right to claim compensation for material and immaterial damage due to bodily injury or the death of a family member". "The compensation values are intended to restore the condition of the injured party which was before the damage was caused" 40 . "The plaintiff has the right to address arbitration after the use of remedies within the insurance company otherwise the lawsuit will be dismissed as premature" 41 . "This means that any claim filed directed to CBK, respectively the arbitral panel for placement without exhaustion of all legal remedies within an insurance company, will be considered premature and as such will be dismissed as premature without entering the review at all of her" "42. Article 5 of RPAT of CBK defines the jurisdiction of the arbitration panel "Arbitration can resolve all matters that are related to the obligation of a police, the extension of a loss or damage and other matters related to the terms of the insurance contract (policy)". "Disputes arising from or relating to an insurance policy may be settled by arbitration tribunals, subject to the agreement of the parties, in accordance with the Law on Arbitration" ${ }^{43}$. CBK is the competent body for maintaining the list of arbitrators, respectively it has the exclusive right to accept or exclude persons from the list of arbitrators. Each arbitrator must be and remain independent of the parties involved in arbitration. "Arbitrators should not be officers, employees or related parties of the insurer, insurance intermediary or claimant ${ }^{44}$. Arbitrators must meet certain conditions, eg to be independent, to be professionals in the respective fields, to be moral, to be objective, to be efficient, etc. All the above mentioned conditions are equally important. Because, in every legislation related to arbitration, it is a

38 Article 3, par. 1 of RPAT of CBK.

39 The Central Bank Board of the Republic of Kosovo at its meeting held on August 31, 2016 approved: "Regulation on the determination of criteria for the assessment of intangible damage from motor liability". This regulation enters into force on 15 September 2016 and applies to all claims for damages are in the process.
40 Article 5, par.1 of RPAT of CBK.
41 Article 4 of RPAT of CBK.
${ }^{42}$ Qehaja, Rr., citated article, page 78.
43 Article 6, par.1 of RPAT of CBK.
${ }^{44}$ Article 7, par.3 of RPAT of CBK. 
prerequisite for an arbitrator to be effective because this is the main reason why the parties choose arbitration. Also, impartiality is a standard required by any contemporary legislation related to arbitration. To be impartial it means, the arbitrator should not be in any familiar, economic, material etc. relationship with the parties of the dispute. If the arbitrator or arbitrators do not possess this qualification, they may be excluded. But we should have in mind that representatives of the party can not be excluded. The party is free to choose a representative, who will represent him/her in the arbitration procedure. "In complex cases when considerable expertise is required in the subject matter of the construction or intellectual property dispute, it is always better to have a panel consisting of an experienced referee in the relevant field" 45 . "The professional qualifications of an arbitrator are important elements for the parties during the selection process, since it is important to have arbitrators who possess appropriate training and education and who have the desirable experience in the role of the arbitrator and their profession in general" ${ }^{46}$. "The person to whom one party is referring to the appointment as an arbitrator has the duty to make public all the circumstances that may give rise to suspicions regarding his impartiality or independence. The arbitrator, upon appointment, must disclose such circumstances before the parties if the parties have not been notified in advance of these circumstances" ${ }^{47}$. The question arises, who selects arbitrators? The parties, respectively the injured party, which requires the realization of the damage compensation in the arbitration procedure, through the request for arbitration, as well as the licensed insurance company, is granted the right to elect an arbitrator from the list of arbitrators as outlined above is managed by CBK. The tribunal of arbitration is composed of just one only arbitrator or a few arbitrators. "Only one arbitrator is needed to resolve disputes in amounts up to one (1) thousand euros or less" 48 . For other cases, the arbitration panel should have three (3) members. The decision is considered to be issued when two (2) arbitrators have voted PRO, but should be written in the decision why the third member did not vote. These cases can appear for e.g when one arbitrator dies, refuses to give his signature etc. Two of arbitrators are freely chosen by parties, while the third one is appointed based on mutual agreement. "In the case of signing the agreement of the parties, by which they acknowledge that the dispute shall be settled through arbitration, the parties may agree on the procedure for appointing an arbitrator or arbitrators" 49 . "Arbitration hearings require at least ten (10) days prior notice to the parties unless such notice has been waived under the signing of the party to whom the notice is intended. "Regarding the submission of documents to the parties, the provisions of LCP that govern this issue in its Chapter VII should be applied"50. The whole

45 "Manual for the Preparation of the Jurisprudence Exam", Part of Civil Law and Civil Procedure law, Kosovo, Pristina, 2015, page 730.

46 Ibid, page 730-731.

47 Article 9, par.1 of RPAT of CBK.

48 Article 8, par. 5 of RPAT of CBK.

49 Article 8, par.2 of RPAT of CBK.

50 Qehaja, Rr., citated article, page 78. 
purpose of developing an arbitration procedure to resolve disputes by the insurance policy is to issue a fair and lawful decision. All of the decisions of tribunal arbitration should be drafted in the written form. The parties should execute all of the decisions without any delay. "The arbitral tribunal shall make a written decision on the case within fifteen (15) days of the date on which the case has been completed" 51 ."The decision is signed by the arbitrator or arbitrators, and maintains the date and place where it is drafted. In the arbitration procedure with more than one arbitrator, the signatures of the majority of tribunal members are sufficient, in the decision should be explained the reasons for the absence of other signatures"52. "The decision outlines the reasons on which the decision is based, unless the parties are agreed that the reasons should not be mentioned and the decision is made public only with the consent of all parties" ${ }^{53}$. "The decision taken by the arbitrators is binding, final, has the power of bailiff title, neither the insurance company nor the claiming party (the plaintiff) can appeal to the court or any other arbitration panel or initiate a dispute for the same case, and for its execution the court is competent" ${ }^{25}$. An exception to this principle is Article 18 of this regulation, which refers to Article 36 of LA. Verified copies of the decision, signed by the arbitrators, will be delivered to the parties by the arbitration institution, respectively by post or courier. The arbitration procedure is kept entirely confidential. The information on the following arbitration proceedings may only be obtained upon written request addressed to the CBK. "A decision may be published, whether in whole or in the form of a fragment or a summary, only under the following conditions:

a. An application for publication is addressed to an arbitration institution;

b. All references to the names of the parties have been cleared; and

c. No party shall object to such publication within the time limit set for this purpose by the arbitration institution" 55 .

Unless the parties agree otherwise, the dissatisfied parties, respectively the insurer (insurance company) and the beneficiary of the insurance policy no later than ninety (90) days after the receipt of the decision of the arbitral tribunal, may file a lawsuit for the annulment of the arbitral decision. "The court annuls the decision of the tribunal if:

a). The plaintiff proves that:

(i) one party to the arbitration agreement has not had the capacity to act;

51 Article 14 of RPAT of CBK.

52 See Article 17, par. 3 of RPAT of CBK and Article 31, par.3 of LA.

53 Article 31, par.2 and 5 of LA.

54 Article 17, par. 1 of RPAT of CBK.

55 Summary of Arbitration Rules, American Chamber of Commerce, Entry Rules, April 19, 2011, Article 41, par. 3 . 
(ii) the arbitration agreement is not valid under the right conferred by either by the arbitral tribunal or, in the absence of such an assignment, according to applicable law in Kosovo;

(iii) the plaintiff has not been properly notified of the appointment of an arbitrator or

on the arbitration procedure, or for other reasons it has been unable to present his case;

(iv) the decision does not relate to the matter examined by the arbitral tribunal or has to deal with a matter for which the arbitral tribunal is not competent, or the decision involves matters for which the arbitral tribunal is not competent.

In these cases, if the decision on matters for which the court is competent arbitration can be separated from other issues, then this part of the decision can be executed;

(v) the composition of the arbitral tribunal or the arbitration procedure was not in accordance with the provisions of this Law or the Arbitration Agreement, provided that such a deficiency has had an impact on the tribunal's decision; or

b). The Court finds that:

(i) the arbitration in question is prohibited by law; or

(ii) the execution of the decision would violate or would conflict with the order public (ordre public) " "56.

During the arbitration procedure it is very normal to incur expenses. The procedural costs are the costs incurred during and in connection with the trial. "It is a rule that the party that looses the judgment not only carries the costs it incurred in its actions but has the duty to pay all the costs to the opposing party"57. The party who lost the judgment fully is obliged to reimburse (compensate) the opposing party all the procedural costs. "Unnecessary expenditures definitely remain chargeable to the party making them, whether or not it has won or lost judgment"s8. "The costs of arbitration procedure include:

a. tribunal arbitration tax;

b. the costs of arbitrators;

c. expenses for experts and other assistance requested by the arbitral tribunal and for which the parties have agreed;

d. travel expenses and other witness expenses, to the extent approved by the arbitral tribunal;

\footnotetext{
56 Article 36, par.2 of LA.

57 Brestovci, F., citated book, page 275.

58 Ibid., page 275.
} 
e. the costs of representation and assistance to the successful party, if the compensation of these expenses is required during the arbitration procedure, and only to the extent that the arbitral tribunal determines it reasonable; and

f. all taxes and court expenses when this makes the appointment of arbitrators" $" 59$.

The arbitral tribunal's fees should be reasonable, taking into account the value of the dispute, the complexity of the case, the time spent by the arbitrators and other circumstances of the case. In the event of disputes regarding the amount of fees to be paid to the arbitral tribunal, the court is competent to decide upon this case" ${ }^{60}$. "Regarding procedural costs, it is a principle that the party who loses the dispute should cover the costs but should also consider such situations when the party partially succeeds in the realization of the right it claims to be entitled to, so in such cases the provisions of Chapter XXV of LCP regarding procedural costs should be applied" ${ }^{61}$.

\section{CONCLUSION}

Currently in the insurance of the Republic of Kosovo, insurance activities are exercised by sixteen (16) insurance companies licensed by the CBK and twelve (12) insurance brokers. To these insurance companies, the demands for material and immaterial (moral) damages from the injured persons, which appear in the quality of third parties, are increasing more and more each day. These claims for material and non-material (moral) compensation can be solved through the use of the arbitration method, as an alternative method of dispute settlement between the parties in the insurance relationship. In states with a contemporary legal system, arbitration holds a special place, and is of great legal importance for dispute settlement. Fortunately in the Republic of Kosovo there is a proper legal infrastructure for arbitration, we can say modern, starting from the Law on Arbitration, to RPAT of CBK, but unfortunately, implementation is not observed in practice or otherwise said, the practical application of these rules has stalled. It is worth considering the initiative of the CBK to issue the relevant normative regulation on the functioning of the arbitral tribunal, but what is to be desired is the practical implementation of this regulation. CBK must do its utmost to raise the awareness of the injured parties, that for the compensation of damage caused to them, to use the arbitration route. CBK should try to put in the consciousness of the injured persons and insurers, once and for all, that the use of the arbitration institution for them would be the most appropriate solution, which would result in an accelerated procedure, development of the procedure with fewer formalities, that the development of the arbitration procedure for them would cause less expenses, that they (the parties) have the possibility of appointing the

59 Article 34, par.1 of LA and Article 11, par.1 of RPAT of CBK.

60 Article 34, par.2 of LA and Article 11, par.2 of RPAT of CBK.

61 Qehaja, Rr., citated article, page 81. 
arbitrators, that the arbitration procedure in comparison with the civil proceedings allows them to be more flexible etc. This is a task, and at the same time a challenge for CBK, because only normative regulation in the theoretical aspect, does not bring any result if the same regulation is not implemented in practice. In the future, CBK should, with all its efforts, try to strengthen the implementation of the arbitration institution in practice. If the legislation on arbitration would be implemented, this would certainly, greatly, affect the reduction of cases in the courts of the Republic of Kosovo, which are burdened with many outstanding cases.

\section{REFERENCES}

Brestovci, F. (2006). Civil procedural law (4th edition). Pristina, Kosovo: University of Pristina, Faculty of Law;

Morina, I., \& Nikçi, S. (2012). Commentary on the Law on contested procedure of Republic of Kosovo. Pristina, Kosovo: Deutsche Gesellschaft für Internationale Zusammenarbeit (GIZ);

"Manual for the Preparation of the Jurisprudence Exam" - Part of Civil Law and Civil Procedure law, Kosovo, Pristina, 2015;

"Manual for the Preparation of Jurisprudence Exam - The part of civil procedural law", Third Edition, Kosovo, Pristina, 2008;

Musa, M. (2015). Civil procedural law (1st edition). Gjilan, Kosovo; Published by House Print "Point 5A";

Law no. 02/L-75, January 26, 2007, on Arbitration of the Republic of Kosovo;

Law no. 03/L-006 on Contested Procedure of the Republic of Kosovo;

Law no. 03/L-199 on Courts of the Republic of Kosovo;

Law no. 04/L-018 for Compulsory Motor Liability Insurance of the Republic of Kosovo;

Law no. 04/L-077 on Obligations of the Republic of Kosovo;

Law no. 05/L -045 on Insurance of the Republic of Kosovo;

Oxford Dictionary [online], available at: https://en.oxforddictionaries.com/definition/ insurance, accessible on 16.12.2017;

Cambridge Dictionary [online], available at: http://dictionary.cambridge.org/dictionary/ english/arbitration, accessible on 16.12.2017. 


\section{PRAVNA REGULACIJA ARBITRAŽE NA KOSOVU S POSEBNIM OSVRTOM NA MJERE OSIGURANJA}

Predmet ovoga rada odnosi se na arbitražu kao metod ili alternativni način riješavanja sporova u osiguranju. U tekstu se raspravlja predmet koji je od posebne važnosti iz jednostavnog razloga osiguranje predstavlja vrlo osjetljivu aktivnost koja pobuđuje interes građana već iz toga što se tom djelatnošću osiguravaju temeljna dobra kao što su život, imanje, itd. U tekstu se autor fokusira na odredbe različitih propisa koji detaljnije regulioraju sektor osiguranja poput Zakona o obveznim odnosima br. 04/L-077, Zakona o osiguranju br. 05/L-045, kao i zakonodavstvo koje pokriva područje arbitriranja, posebno se to osnosi na Zakon o arbitraži Republike Kosovo no. 02/L-75. Rješavanje stranačkih sporova o mjerama osiguranja arbitražom daje ovom predmetu poseban karakter iz razloga što se arbitriranje u ovom području nije posebno istraživalo i analiziralo osim kada je to bilop nužno samo po sebi. Svrha ovoga teksta je da čitaocima pruži opće znanje o arbitraži kao alternativnom načinu riješavanja sporova između stranaka u osiguranju.

Ključne riječi: arbitraža, osiguranje, mjere osiguranja, Zakon o osiguranju, Zakon o arbitraži 